\title{
What to avoid to succeed as an entrepreneuris
}

\author{
Alicia Mas-Tur ${ }^{\mathrm{a}, *}$, Pablo Pinazo ${ }^{\mathrm{b}, *}$, Ana María Tur-Porcar ${ }^{\mathrm{c}, *}$, Manuel Sánchez-Masferrer $^{\mathrm{d}}$ \\ a Universitat de València, Departamento de Dirección de Empresas, Avenida Tarongers, S/N, 46022, Valencia, Spain \\ b ESIC, Avda. Blasco Ibáñez, 55, 46021, Valencia, Spain \\ c Universitat de València, Departamento de Psicología Básica, Blasco Ibañez, 46010, Valencia, Spain \\ ${ }^{\text {d }}$ ESEN, carretera al Puerto de La Libertad, calle nueva a Comasagua, Santa Tecla La Libertad, San Salvador, El Salvador
}

\section{A R T I C L E I N F O}

\section{Article history:}

Received 1 September 2014

Received in revised form 1 March 2015

Accepted 1 April 2015

Available online 11 June 2015

\section{Keywords:}

Entrepreneurship

Success

Emerging economies

QCA

\begin{abstract}
A B S T R A C T
Entrepreneurship is a driver of economic growth and development. This study highlights the importance of entrepreneurship in emerging countries and examines entrepreneurs' characteristics in these countries. In particular, the study explains what entrepreneurs should avoid to succeed in Latin America. An empirical study analyzes factors that relate to businesses and entrepreneurs in El Salvador, one of the Latin American countries with the lowest rates of business success. In the study, business factors consist of the use of formal and informal advisory services and the degree of innovation. Variables that relate to the entrepreneur are educational attainment and the demographic variables sex and age. Results from analysis of 2012 GEM data using csQCA methodology show that degree of innovation, professional advisory services, and educational attainment play key roles in business success.
\end{abstract}

(c) 2015 Elsevier Inc. All rights reserved.

\section{Introduction}

Entrepreneurship contributes to economic growth, productivity, and renewal of productive and social networks (Audretsch \& Thurik, 2001; Kantis et al., 2002). This functionality boosts interest in entrepreneurship. Studies show that entrepreneurship helps to revitalize regional identity, which drives the innovation process and creates employment opportunities (Audretsch \& Thurik, 2001). Latin America has one of the world's highest rates of entrepreneurial activity (Acs et al., 2008; Weeks \& Seiler, 2001). Nevertheless, Latin American economy is much less dynamic than other emerging regions' economy, especially because of the high rates of necessity-based entrepreneurship and the low value added of opportunities in the region (Amorós \& Cristi, 2008; Autio, 2005; Kantis et al., 2004; Minniti et al., 2006). The high rate of entrepreneurial failure reflects these features (Sánchez-Masferrer, 2013).

Latin American countries have Latin European cultural influences, but differ culturally, racially, and economically. These differences affect businesses' size and characteristics. Whereas numerous studies address entrepreneurship in Europe and North America, Latin America remains a novel target for entrepreneurship research (de Arruda, 2009). This article fills the research gap by examining the characteristics that entrepreneurs should seek to achieve to succeed in El Salvador, one of the

\footnotetext{
it Authors are grateful to contributions from Domingo Ribeiro-Soriano and Norat RoigTierno for their assistance with methodology.

* Corresponding authors.

E-mail addresses: alicia.mas@uv.es (A. Mas-Tur), pablo.pinazo@esic.edu (P. Pinazo), ana.tur@uv.es (A.M. Tur-Porcar).
}

Latin American countries with the highest rate of business failure (Sánchez-Masferrer, 2013). The study adopts an original approach, establishing guidelines for what entrepreneurs should avoid to succeed.

The study draws on 2012 GEM data for El Salvador. The GEM project provides a tool to study entrepreneurial dynamics in detail, offering information at the regional or national level (Bosma \& Levie, 2010). The study employs csQCA methodology, an optimal tool for analyzing complex causal relations in contexts where researchers work with mediumsized samples (Eng \& Woodside, 2012).

Section 2 contains a review of the literature on certain characteristic variables of entrepreneurs in emerging countries. Section 3 explains the csQCA methodology and presents results. The final section presents the conclusions, and discusses limitations and opportunities for further research.

\section{Theoretical framework}

A preliminary review of the literature on entrepreneurial characteristics in emerging countries shows the characteristics that successful or unsuccessful entrepreneurs embody. This review focuses on specific characteristics of Latin America.

Specifically, the following review discusses key findings on: (i) variables that relate to access to advisory services, separating professional from informal services (i.e., advice from family and friends); (ii) the educational attainment of the entrepreneur; (iii) the degree of innovation of the entrepreneur's business; (iv) and sex and age-two of the most common sociodemographic variables that characterize entrepreneurs within a nation or region. 


\subsection{Professional or informal advisory services}

Professional advisory services include services in areas such as strategy, design, engineering, and consulting, as well as technical areas such as IT, advertising, and marketing (Belso-Martinez et al., 2013; Nielsen \& Lassen, 2012; Simmie \& Strambach, 2006). Thus, professional advisory service creates and transfers knowledge, which is crucial during the entrepreneurial process.

Advisory services act as a source of external knowledge, while contributing to entrepreneurship and innovation. Miles (2005) defines advisory services as the range of services for private enterprises and public institutions. These services help companies to perform complex operations to resolve problems in which the role of human capital is essential. Advisory services accomplish essential tasks for entrepreneurship, incorporating knowledge-intensive activities into the production process of other firms (García-Quevedo et al., 2012).

The literature contains diverse definitions of professional services. Authors equate professional services to knowledge-intensive services necessary to create and develop a business (Audretsch, 2012; Den Hertog et al., 2010; García-Quevedo et al., 2012). Miles (2005) define these services as those with roots in people's knowledge-professional knowledge. Mas-Verdú et al. (2011) assert that professional advisory services encompass a wide variety of services that range from advertising to legal services, whereby providers may be consultants, advisors, engineers, or analysts. Bettencourt et al. (2002) define businesses that provide these services as those whose main activity is accumulating, creating, and disseminating knowledge to develop a service or product to meet customers' needs. Finally, Muller and Zenker (2001) points out that knowledge-intensive services add much intellectual value.

Informal counsel is an important component of entrepreneurial success (Singh et al., 2001). An extensive body of research investigates the influence of parents (Belcourt, 1991; Bowen \& Hisrich, 1986; Scherer et al., 1989; Watkins \&Watkins, 1983), family, or friends (Akehurst et al., 2012; Cromie \& Birley, 1991; Ibarra, 1993). Gatewood et al. (1995) report that $88 \%$ of veteran entrepreneurs have a higher performance than new entrepreneurs do. Watkins and Watkins (1983) also state that sons of entrepreneurs are four times more likely than the rest of the population to become an entrepreneur. Ronstadt (1984) shows that entrepreneurs usually come from families in which parents are business owners.

Emerging economies have, in general, institutional frameworks that differ greatly from those of developed economies (Bruton \& Ahlstrom, 2003; He et al., 2007). Particularly, emerging economies usually have inadequate regulations and inefficient systems to guarantee conformity to regulations (Peng, 2000). Many emerging countries lack adequate legal frameworks to ensure that parties honor contracts, which often forces companies to rely on alternative and less formal mechanisms such as personal relations, agreements with private security to ensure that counterparties meet their contractual obligations (Ahlstrom et al., 2003; Tung, 2002; Tung \&Worm, 2001). Likewise, belonging to a business network is of the utmost importance. In the early stages of entrepreneurship, belonging to a business network allows firms to identify and exploit market opportunities and to access certain resources (information, technology, etc.) and the knowledge necessary to confront business problems or challenges (Kantis et al., 2002).

All Latin American countries, however, display growing interest in entrepreneurship and its implications, and Latin American institutions gradually implement plans to foster entrepreneurial activities. Such plans include encouraging business creation and self-employment because these activities are powerful enhancers of regional development in social and economic terms (Tiffin, 2004).

Consistent with Klapper et al. (2006) and Djankov et al. (2002), recognizing the importance of entrepreneurship and the needs of markets where entrepreneurs operate leads numerous countries to reform their policies. Such actions improve markets by removing barriers to entrepreneurship and market failures. Evidence of this trend also comes from International Organizations for Development's new approach, which aims to develop the private sector, enhance the business environment, and improve policies for firms.

In short, both formal and informal institutions in Latin American seemingly need to play a prominent role to improve and foster entrepreneurship (Terjesen \& Amorós, 2010).

Proposition 1. The success of a new business depends on the professional and informal advisory network that the business uses.

\subsection{Educational attainment}

In many cases, entrepreneurs prefer self-learning and learning by doing over formal learning after starting a business venture (Martin \& Halstead, 2003). Hughes (2001) defines informal learning as any activity involving the quest for understanding, knowledge, and skills, and occurring outside educational institutions, workshops, or taught courses. Thus, business training becomes increasingly important for tomorrow's society (Lee et al., 2006).

Nonetheless, several studies show that the lack of business training constitutes a professional weakness because business training is necessary to perform certain business functions that fundamentally relate to management and modern technologies (Lerner \& Almor, 2002).

Amorós et al. (2012) point out that some Latin American regions' economic transformation is less noticeable than other emerging economies such as South Korea, Singapore, Israel, and Ireland, in terms of both economic growth and institutional development. Countries owe this lower economic transformation to regional weaknesses in education and knowledge creation. Acs and Amorós (2008) claim that these weaknesses in education explain the greater difficulty to perform activities such as entrepreneurship or business creation. Despite Latin American countries' efforts over the last 20 years to instill democracy, property rights, and macroeconomic stability, these countries have yet to strengthen areas such as education, knowledge creation, and economic reforms (Acs \& Amorós, 2008).

Proposition 2. Entrepreneurial success relates to entrepreneurs' educational attainment.

\subsection{Innovation}

Innovation is one of the key factors of entrepreneurship (Braunerhjelm, 2011; Cuervo et al., 2007; Sternberg \& Wennekers, 2005). Innovation is a component not only of entrepreneurial activity, but also of the capability to discover, evaluate, and exploit opportunities that the market brings within entrepreneurs' reach (Shane \& Venkataraman, 2000). Innovation contributes not only specifically to business performance, but also to the economic well-being and wealth creation of a region or country (Braunerhjelm, 2011; Holcombe, 1998; Huarng \& Ribeiro-Soriano, 2014; Wennekers \& Thurik, 1999).

Because of numerous restrictions to create knowledge-based firms, countries in Latin America are not strictly entrepreneurial economies with roots on innovation and competitiveness (Kantis et al., 2004). As per Acs and Amorós (2008), most developed countries and other emerging regions (e.g., The East Asian Miracle) moved from the efficiency-driven stage to the innovation-driven stage of development, whose foundations lie in knowledge spillover, greater competition, and diversity between major firms. This status allows flexibility and innovation in the economy whereby new firms are fundamental to improve technology and innovation.

Latin American countries still experience low technological and innovation development. Only large firms absorb business opportunities that build on technology and innovation. Likewise, only large firms have the sufficient structure to maximize profits through exports, and 
only a few small enterprises have the necessary capabilities to become high-growth, internationally-oriented firms.

Proposition 3. Innovation influences the creation of successful firms.

\subsection{Age and sex}

The influence of the entrepreneur's age on successfully creating a business is unclear. No direct relationship seems to exist between age and profit growth, as Bates (2002), and Lerner and Almor (2002) report. Singh et al. (2001) report that the probability that women under 40 undertake an entrepreneurial activity is low and that male entrepreneurs are usually younger than women entrepreneurs are. Minniti and Bygrave's (2001) findings, however, show that the pattern of entrepreneurial activities does not vary between countries, and neither does the predominance of one sex with respect to the entrepreneur's age. Finally, businesses that belong to younger women usually encounter greater difficulty in securing financing because of the business owner's age, which provides an insufficient guarantee to investors or creditors (Coleman, 2000).

Several scholars note that developed and underdeveloped regions fail to harness women entrepreneurs' potential and women's capabilities to drive economic development through entrepreneurial activity (Terjesen \& Amorós, 2010). The proportion of women entrepreneurs in Latin America is below that of the most advanced countries in Europe, Asia, and North America. Women entrepreneurship in Latin America is diverse and spans all sectors of the economy, but differences between the sexes are considerable in terms of incentives to start a business (Allen et al., 2008; Amorós \& Pizarro, 2007).

Furthermore, inequality between men and women means that women face adverse situations even when women have the necessary skills and knowledge and a favorable stance towards entrepreneurship. Women in Latin America generally engage in entrepreneurship in small business such as in retail, even though women's role becomes increasingly important for these economies because of their growing participation in the labor market and in entrepreneurial activities (Amorós \& Pizarro, 2007). El Salvador shows this tendency, with consistently growing rates of women entrepreneurship, albeit mainly necessity-driven entrepreneurship (Sánchez-Masferrer, 2013).

In this vein, analysis by the National Foundation of Women Business Owners (NFWBO) of the relation between women's activity as business owners and economic growth reveals a relationship between women's business ownership activity and economic growth (NFWBO, 1998). Similarly, the Organization for Economic Co-operation and Development's (OECD) 2004 report acknowledges the key role of women business owners in creating employment.
Proposition 4. Variables that relate to age and sex of the entrepreneur affect Latin American firms' success.

\section{Methodology and results}

Entrepreneurship is a complex phenomenon that encompasses multiple factors at individual, business, and environmental levels. This empirical study analyzes data from the Global Entrepreneurship Monitor (GEM); specifically, information about El Salvador for the year 2012, the first year of data collection for El Salvador. The database contains primary information about entrepreneurship in El Salvador, from a survey of 2180 households across the country. The El Salvador National Report 2012 concisely describes the data collection methodology and other relevant information from the data collection procedure. The GEM project offers a better understanding of entrepreneurship: first, by producing a series of indicators ideal for studying entrepreneurial dynamics in detail; and second, by offering information from a regional and national perspective (Bosma \& Levie, 2010).

This study selects only new entrepreneurs from the database. According to GEM, a new entrepreneur is an individual who owns or manages an active business that is 3 to 42 months old. Following the data cleansing process, 198 usable cases remain. The study employs qualitative comparative analysis (QCA). This technique, as Woodside (2012) demonstrates, is suitable for this type of research. QCA is a novel research methodology that combines Boolean logic and the principles of comparison. QCA examines how variables combine to cause a certain outcome (Ragin, 1987, 2000). Ragin (2008) lists the main contrasts between QCA and other quantitative analysis techniques: set theory versus correlations, calibrating variables versus measuring, and causal analysis versus the analysis of net effects.

In general, QCA is useful when analyzing small- $N$ samples (i.e., between 10 and 50 cases) (Collier, 1993; Fiss, 2011; Lijphart, 1971). Nevertheless, QCA is also useful when studying large- $N$ samples (Fiss, 2011; Ragin, 1987, 2006; Woodside, 2012). Thus, this study also exemplifies the suitability of applying QCA to large- $N$ samples.

This study deploys crisp-set QCA (csQCA), one of the many modes of qualitative comparative analysis. The main feature of csQCA is that all variables must be dichotomous; that is, cases must all be either fully into or fully out from any set. The name of this operation is calibration (Ragin, 2000).

Table 1 displays the variables that form part of the study, along with the corresponding calibration.

The fsQCA software program (Ragin \& Davey, 2014) provides the tool for data analysis in this study. To understand how qualitative comparative analysis works, a notion of the difference between necessary

Table 1

Definition and calibration of causal conditions.

\begin{tabular}{|c|c|c|}
\hline Variable & Definition & Calibration \\
\hline Success & $\begin{array}{l}\text { The firm is profitable and does not close because of a lack of } \\
\text { profitability }\end{array}$ & $\begin{array}{l}0 \text { : firms that do not pay dividends and close because of a lack of profitability } \\
\text { 1: firms that pay dividends and do not close as a result of lack of profitability }\end{array}$ \\
\hline Innovation & The firm's degree of innovation & $\begin{array}{l}\text { 0: firms whose customers do not consider their products or services to be innovative } \\
\text { 1: firms whose customers consider their products or services to be innovative }\end{array}$ \\
\hline Education & Educational attainment of the entrepreneur & $\begin{array}{l}0: \text { The entrepreneur has a maximum of basic compulsory studies } \\
\text { 1: The entrepreneur has at least higher education }\end{array}$ \\
\hline $\begin{array}{l}\text { Professional advisory } \\
\text { services }\end{array}$ & $\begin{array}{l}\text { Use of advisory services from public or private institutions that } \\
\text { specialize in offering knowledge-intensive services }\end{array}$ & $\begin{array}{l}\text { 0: The entrepreneur does not use advisory services from public or private institutions } \\
\text { that specialize in offering professional knowledge-intensive services } \\
\text { 1: The entrepreneur uses advisory services from public or private institutions that } \\
\text { specialize in offering professional knowledge-intensive services }\end{array}$ \\
\hline $\begin{array}{l}\text { Informal advisory } \\
\text { services }\end{array}$ & Use of advice from family or friends & $\begin{array}{l}0: \text { The entrepreneur does not use advice from family or friends } \\
1 \text { : The entrepreneur uses advice from family or friends }\end{array}$ \\
\hline Sex & Sex of the entrepreneur & $\begin{array}{l}0 \text { : male } \\
1 \text { : female }\end{array}$ \\
\hline Age & Age of the entrepreneur & $\begin{array}{l}0: \text { less than } 40 \text { years old (young entrepreneur) } \\
\text { 1: more than } 40 \text { years old }\end{array}$ \\
\hline
\end{tabular}


and sufficient conditions analysis is essential. As per Ragin (2006), a condition is necessary for a specific outcome if that condition always holds when the outcome occurs. In contrast, if a condition is sufficient, the outcome always occurs when that condition holds, although outcomes may occur under different conditions. In this study, the first stage of analysis shows that no variable is necessary for the outcome. The analysis second stage reveals the causal configurations that are sufficient to lead to the outcome.

Table 2 displays the intermediate solution of the sufficient condition analysis, presenting for each solution the set of sufficient causal conditions; the unique coverage, raw coverage, and consistency of each configuration that constitutes the solution; and the solution coverage and consistency. QCA yields the intermediate solution-an alternative solution with intermediate complexity-by assuming that only a subset of the possible causal configurations for which the data do not contain empirical observations would have led to the outcome. To determine this intermediate solution, the researcher must decide which of the logical remainders to include in the solution. Specifically, in this study, and in accordance with the most recent literature, the absence of the variables innovation, education, and the use of professional advisory services should lead to the outcome absence of success (i.e., failure).

QCA thereby tests the following model:

$\sim$ Success $=$ (age, sex, informal counsel, professional advisory services, educational attainment, innovation)

Coverage is 0.60 , and consistency is 0.85 ; that is, the model explains $60 \%$ of cases depicting failing business. Ragin (2006) recommends a minimum consistency of 0.75 in the case of necessary conditions analysis, deeming causal conditions with consistency below this threshold irrelevant. Their inclusion in the solution may yield incorrect results (Braumoeller \& Goertz, 2000). Four configurations explain the highest percentage of cases:

$\sim$ inno $*$ educ $*$ inform

0.1642

The first group of failing businesses do not innovate, and focus on advice from family or friends (not professional), although the entrepreneur has a high educational attainment.

inno $* \sim$ educ $*$ gen_1m_0h $*$ edad_1 jov

0.1500

Failing firms, despite innovating, have a male owner who is under 40 years old and who lacks higher education.

$\sim$ profesi $*$ inform $*$ gen_1m_0h $*$ edad_1 jov

0.1785
Another group of failing businesses comprises firms that, once again, do not use professional advisory services, but take advice from family and friends, and whose owner is male and less than 40 years old.

inno $* \sim$ profesi $* \sim$ inform

Finally, the last combination of variables implies that some firms from the sample, albeit innovative, do not use any type of advisory services, be they professional or informal (i.e., family and friends).

The most salient findings among unsuccessful firms are as follows: innovation, education, and the use of professional advisory services alone fail to guarantee success for firms. Entrepreneurs must consider a combination of variables if they wish to create a successful firm. Thus, if an entrepreneur takes advice only from friends and family, has a low level of educational attainment, and fails to innovate in any area, his or her firm may fail. Conversely, if the entrepreneur receives help from professionals, his or her chances of failure decrease. Entrepreneurs achieve the same outcome if the firm innovates in some area or if the entrepreneur tries to develop knowledge about firm creation.

\section{Conclusions}

This research studies the characteristics of failing entrepreneurs in the Latin American region of El Salvador to establish guidelines for what to avoid to succeed in a region with these characteristics. This study draws on a sample of data for El Salvador from the GEM project. The study then tests a set of variables that, consistent with the literature, relate to business success to observe the characteristics of entrepreneurs whose businesses fail. QCA methodology, a comparative analysis tool (Ragin, 1987), analyzes causal relations between certain variables within a context, thereby overcoming the main limitations of traditional probabilistic statistical techniques, and yielding highly interesting results.

A particularly interesting observation is that the use of professional advisory services when creating a firm strongly correlates with the subsequent success or failure of the business. Results show that firms that do not use this type of advisory services, and instead only receive guidance from friends and family, tend to fail. As this study discusses, emerging economies usually have inadequate regulations to foster entrepreneurship (Peng, 2000). Developing these services is necessary to encourage their usage among entrepreneurs, thereby increasing Latin American business success probabilities. Innovation itself is not a guarantee of success if other variables such as a high educational attainment do not follow. As the literature review discusses, weaknesses in education explain greater difficulty in performing activities such as entrepreneurship or business creation (Acs \& Amorós, 2008). Therefore, education policymakers in emerging regions should continue strengthening education, because education positively affects numerous areas of society by, for instance, fostering successful entrepreneurial activity and consequently increasing employment, salaries, and so forth.

Table 2

Intermediate solution of the model.

\begin{tabular}{lll}
\hline & Raw coverage & Unique coverage \\
\hline$\sim$ inno*educ*inform & 0.164286 & 0.128571 \\
inno* $\sim$ educ*gen_1m_0h*edad_1jov & 0.150000 & 0.050000 \\
$\sim$ profesi*inform*gen_1m_0h*edad_1jov & 0.178571 & 0.071429 \\
inno* $\sim$ profesi* $\sim$ inform & 0.085714 & 0.057143 \\
inno* $\sim$ inform* $\sim$ gen_1m_0h*edad_1jov & 0.021429 & 0.007143 \\
$\sim$ educ* $\sim$ profesi*inform* $\sim$ gen_1m_0h* $\sim$ edad_1jov & 0.050000 & 0.050000 \\
$\sim$ inno* educ*profesi* $\sim$ gen_1m_0h*edad_1jov & 0.014286 & 0.014286 \\
inno*profesi*inform* $\sim$ gen_1m_0h* $\sim$ edad_1jov & 0.064286 & 0.0645286 \\
$\sim$ inno*profesi*inform*gen_1m_0h* edad_1jov & 0.021429 & 0.777778 \\
\hline
\end{tabular}

Solution coverage: 0.600000 .

Solution consistency: 0.857143. 
This research has limitations. In particular, the literature has a large gap on how Latin American companies finance their operations. Market conditions restrict these firms because of scarce availability of internal financial and management resources in comparison with larger firms. Thus, the main barrier to development that Latin American companies must face is financing; a consequence of the scarce resources that these countries' banking systems offer. This restriction negatively affects firms' competitiveness and survival options (FAEDPYME, 2009). This variable is missing from the analysis, despite its great importance, because of GEM database limitations. To remedy this shortcoming, future research should include a variable that addresses access to financing because such a variable may clarify many start-ups failure in emerging countries.

\section{References}

Acs, Z.J., \& Amorós, J.E. (2008). Entrepreneurship and competitiveness dynamics in Latin America. Small Business Economics, 31(3), 305-322.

Acs, Z.J., Desai, S., \& Klapper, L.F. (2008). What does "entrepreneurship" data really show? Small Business Economics, 31(3), 265-281.

Ahlstrom, D., Young, M.N., \& Nair, A. (2003). Navigating China's feudal governance structures: Some guidelines for foreign enterprises. SAM Advanced Management Journal, 68(1), 4-13.

Akehurst, G., Simarro, E., \& Mas-Tur, A. (2012). Women entrepreneurship in small service firms: motivations, barriers and performance. The Service Industries Journal, 32(15), 2489-2505.

Allen, E., Elam, A., Langowitz, N., \& Dean, M. (2008). The Global Entrepreneurship Monitor (GEM) 2007 report on women and entrepreneurship. Babson Park, MA - New York: Babson College and Baruch College.

Amorós, J.E., \& Cristi, O. (2008). Longitudinal analysis of entrepreneurship and competitiveness dynamics in Latin America. International Entrepreneurship and Management Journal, 4(4), 381-399.

Amorós, J.E., Fernández, C., \& Tapia, J. (2012). Quantifying the relationship between entrepreneurship and competitiveness development stages in Latin America. Internationa Entrepreneurship and Management Journal, 8(3), 249-270.

Amorós, J.E., \& Pizarro, O. (2007). Women entrepreneurship context in Latin America: An exploratory study in Chile. In M.R. Markovic (Ed.), The perspective of women's entrepreneurship in the age of globalization (pp. 107-126). Charlotte, NC: Information Age Publishing.

Audretsch, D. (2012). Entrepreneurship research. Management Decision, 50(5), 755-764.

Audretsch, D., \& Thurik, R. (2001). What is new about the new economy? Sources of growth in the managed and entrepreneurial economy. Industrial and Corporate Change, 10(1), 267-315

Autio, E. (2005). GEM report on high-expectation entrepreneurship. Wellesley MA: London Business School, Mazars \& Babson College.

Bates, T. (2002). Restricted access to markets characterizes women-owned businesses. Journal of Business Venturing, 17(4), 313-324.

Belcourt, M. (1991). From the frying pan into the fire: Exploring entrepreneurship as a solution to the glass ceiling. Journal of Small Business E' Entrepreneurship, 8(3), 49-55.

Belso-Martinez, J.A., Molina-Morales, F.X., \& Mas-Verdu, F. (2013). Combining effects of internal resources, entrepreneur characteristics, and KIS on new firms. Journal of Business Research, 66(10), 2079-2089.

Bettencourt, L., Ostrom, A., Brown, S., \& Roundtree, R. (2002). Client co-production in KIBS. California Management Review, 44, 100-128.

Bosma, N., \& Levie, J. (2010). Global entrepreneurship monitor, 2009 global report. Wellesley: Babson College.

Bowen, D.D., \& Hisrich, R.D. (1986). The female entrepreneur: A career development perspective. Academy of Management Review, 11(2), 393-407.

Braumoeller, B.F., \& Goertz, G. (2000). The methodology of necessary conditions. American Journal of Political Science, 44, 844-858.

Braunerhjelm, P. (2011). Entrepreneurship, innovation, and economic growth: interdependencies, irregularities, and regularities. Handbook of research on innovation and entrepreneurship. Elgar: Cheltenham, 161-213.

Bruton, G.D., \& Ahlstrom, D. (2003). An institutional view of China's venture capital industry: Explaining the differences between China and the West. Journal of Business Venturing, 18(2), 233-259.

Coleman, S. (2000). Access to capital and terms of credit: A comparison of men and women-owned small businesses. Journal of Small Business Management, 38(3), 37-52.

Collier, D. (1993). The comparative method. In A.W. Finifter (Ed.), Political science: The state of discipline II (pp. 105-119). American Political Science Association: Washington.

Cromie, S., \& Birley, S. (1991). Networking by female business owners in Northern Ireland. Journal of Business Venturing, 7(3), 237-251.

Cuervo, A., Ribeiro, D., \& Roig, S. (2007). Entrepreneurship: Concepts, theory and perspective. Springer

deArruda, M.C. (2009). Ethics and corporate social responsibility in Latin-American small and medium sized enterprises: Challenging development. African Journal of Business Ethics, 4(2), 37-47.

Den Hertog, P., Van der Aa, W., \& de Jong, M.W. (2010). Capabilities for managing service innovation: Towards a conceptual framework. Journal of Service Management, 21(4), 490-514.
Djankov, S., La Porta, R., Lopez-de-Silanes, F., \& Shleifer, A. (2002). The regulation of entry. Quarterly Journal of Economics, 117, 1-37.

Eng, S., \& Woodside, A.G. (2012). Configural analysis of the drinking man: Fuzzy-set qualitative comparative analyses. Addictive Behaviors, 37(4), 541-543.

FAEDPYME (2009). "Análisis estratégico del desarrollo de las MIPYME en Iberoamérica.". España: Universidad Politécnica de Cartagena.

Fiss, P.C. (2011). Building better causal theories: A fuzzy set approach to typologies in organization research. Academy of Management Journal, 54(2), 393-420.

García-Quevedo, J., Mas-Verdú, F., \& Polo-Otero, J. (2012). Which firms want PhDs? An analysis of the determinants of the demand. Higher Education, 63(5), 607-620.

Gatewood, E.J., Shaver, K.G., \& Gartner, W.B. (1995). A longitudinal study of cognitive factors influencing start-up behaviors and success at venture creation. Journal of Business Venturing, 10(5), 371-391.

He, Y., Tian, Z., \& Chen, Y. (2007). Performance implications of nonmarket strategy in China. Asia Pacific Journal of Management, 24(2), 151-169.

Holcombe, R.G. (1998). Entrepreneurship and economic growth. Quarterly journal of Austrian economics, 1(2), 45-62.

Huarng, K.H., \& Ribeiro-Soriano, D.E. (2014). Developmental management: Theories, methods, and applications in entrepreneurship, innovation, and sense making. Journal of Business Research, 67(5), 657-662.

Hughes, K.D. (2001). Self-employment, skill development and training in Canada Vol.1. Applied Research Branch, Human Resources Development Canada.

Ibarra, H. (1993). Personal networks of women and minorities in management: A conceptual framework. Academy of Management Review, 18(1), 56-87.

Kantis, H., Angelelli, P., \& Moori-Koenig, V. (2004). Experience in Latin America and worldwide. Washington, DC: Inter-American Development Bank-Fundes International.

Kantis, H., Ishida, M., \& Komori, M. (2002). Entrepreneurship in emerging economies: The creation and development of new firms in Latin America and East Asia. InterAmerican Development Bank.

Klapper, L., Laeven, L., \& Rajan, R. (2006). Entry regulation as a barrier to entrepreneurship. Journal of Financial Economics, 82(3), 591-629.

Lee, S.M., Lim, S.B., Pathak, R.D., Chang, D., \& Li, W. (2006). Influences on students attitudes toward entrepreneurship: a multi-country study. The International Entrepreneurship and Management Journal, 2(3), 351-366.

Lerner, M., \& Almor, T. (2002). Relationships among strategic capabilities and the performance of women-owned small ventures. Journal of Small Business Management, 40(2), 109-125.

Lijphart, A. (1971). Comparative politics and comparative method. The American Political Science Review, 65(3), 682-693.

Martin, L.M., \& Halstead, A. (2003). Knowledge and learning in female team-managed firms adopting information communication technologies (ICTs). Women in Management Review, 18(6), 334-337.

Mas-Verdú, F., Wensley, A., Alba, M., \& Álvarez-Coque, J.M.G. (2011). How much does KIBS contribute to the generation and diffusion of innovation? Service Business, 5(3), 195-212.

Miles, I. (2005). Knowledge intensive business services: Prospects and policies. ForesightThe journal of future studies, strategic thinking and policy, 7(6), 39-63.

Minniti, M., \& Bygrave, W. (2001). A dynamic model of entrepreneurial learning. Entrepreneurship: Theory and Practice, 25(3), 5-16.

Minniti, M., Bygrave, W.D., \& Autio, E. (2006). Global entrepreneurship monitor-executive report 2005. Wellesley, MA: Babson College-London Business School.

Muller, E., \& Zenker, A. (2001). Business services as actors of knowledge transformation: The role of KIBS in regional and national innovation systems. Research Policy, 30(9), 1501-1516.

National Foundation of Women Business Owners (1998). Women entrepreneurs are a growing trend. Washington, DC: National Foundation of Women Business Owners.

Nielsen, S.L., \& Lassen, A.H. (2012). Images of entrepreneurship: Towards a new categorization of entrepreneurship. International Entrepreneurship and Management Journal, $8(1), 35-53$.

OECD, I. (2004). OECD principles of corporate governance. Competition in

Peng, M.W. (2000). Business strategies in transition economies. Thousand Oaks, CA: Sage Publications.

Ragin, C.C. (1987). The comparative method. Moving beyond qualitative and quantitative strategies. Berkeley: University of California Press.

Ragin, C.C. (2000). Fuzzy-set social science. Chicago: University of Chicago Press.

Ragin, C.C. (2006). How to lure analytic social science out of the doldrums some lessons from comparative research. International Sociology, 21(5), 633-646.

Ragin, C.C. (2008). Redesigning social inquiry: Fuzzy sets and beyond. Chicago: University of Chicago Press.

Ragin, C., \& Davey, S. (2014). fs/QCA [Computer Programme], Version 2.5. Irvine, CA: University of California.

Ronstadt, R. (1984). Ex-entrepreneurs and the decision to start an entrepreneurial career. Frontiers of entrepreneurship research, 437-460

Sánchez Masferrer, M. (2013). Global entrepreneurship monitor: Informenacional El Salvador 2012. San Salvador: ESEN.

Scherer, R.F., Adams, J.S., Carley, S., \& Wiebe, F.A. (1989). Role model performance effects on development of entrepreneurial career preference. Entrepreneurship: Theory and Practice, 13(3), 53-71.

Shane, S., \& Venkataraman, S. (2000). The promise of entrepreneurship as a field of research. Academy of Management Review, 25(1), 217-226.

Simmie, J., \& Strambach, S. (2006). The contribution of KIBS to innovation in cities: an evolutionary and institutional perspective. Journal of Knowledge Management, 10(5), $26-40$.

Singh, V., Vinnicombe, S., \& Johnson, P. (2001). Women directors on top UK boards. Corporate Governance, 9(3), 206-216. 
Sternberg, R., \& Wennekers, S. (2005). Determinants and effects of new business creation using global entrepreneurship monitor data. Small Business Economics, 24(3), 193-203.

Terjesen, S., \& Amorós, J.E. (2010). Female entrepreneurship in Latin America and the Caribbean: Characteristics, drivers, and relationship to economic development. European Journal of Development Research, 22(3), 313-330.

Tiffin, S. (2004). Entrepreneurship in Latin America: Perspectives on education and innovation. Praeger Publishers.

Tung, R.L. (2002). Building effective networks. Journal of Management Inquiry, 11(2), 94-101.

Tung, R.L., \& Worm, V. (2001). Network capitalism: The role of human resources in penetrating the China market. International Journal of Human Resource Management, 12(4), 517-534.
Watkins, J., \& Watkins, D. (1983). The female entrepreneur: Her background and determinants of business choice-some British data. International Small Business Journal, 2(4), 21-31.

Weeks, J.R., \& Seiler, D. (2001). Women's entrepreneurship in Latin America: An exploration of current knowledge. Inter-American Development Bank.

Wennekers, S., \& Thurik, R. (1999). Linking entrepreneurship and economic growth. Small Business Economics, 13(1), 27-56.

Woodside, A.G. (2012). Proposing a new logic for data analysis in marketing and consumer behavior: Case study research of large-N survey data for estimating algorithms that accurately profile X (extremely high-use) consumers. Journal of Global Scholars of Marketing Science, 22(4), 277-289. 